\title{
A mathematical modelling for the COVID-19 pandemic in Iran
}

\section{Iran'daki COVID-19 pandemisi için matematiksel bir modelleme}

\author{
Zafer Cakir ${ }^{1}$ (D), Hasan Basri Savas ${ }^{2^{*}}$ \\ ${ }^{1}$ Alanya Keykubat University Faculty of Education, Mathematics Education Department, Antalya, Turkey \\ ${ }^{2}$ Alanya Keykubat University School of Medicine, Department of Medical Biochemistry, Antalya, Turkey \\ * Corresponding author: Hasan Basri Savaş E-mail: hasan.savas@alanya.edu.tr ORCID: 0000-0001-8759-4507 \\ Received: 6 April 2020 Accepted: 7 April 2020
}

\begin{abstract}
The novel coronavirus which is known as SARS-CoV-2 or COVID-19 emerged in China with the first clinical case in December 2019 , and afterwards, it has turned into a global problem very fast. Iran is a crowder Middle Eastern country with a population of 82531700. Until 31.03.2020, the number of cases in Iran reached 44605, and 2898 patients lost their lives. This study aimed to simulate the progression of the COVID-19 pandemic in Iran with modified mathematical modelling established based on the information that the time-dependent change (spreading rate) in the number $\mathrm{P}$ of the individuals who has caught a contagious disease is proportional to the multiplication of the numbers of those who have caught the disease and those who have not. If the precautions are increased a little bit, as its reflection on the progression of the disease would be "exponential", it seems possible for the number of cases to decrease down to around 120 thousand and for the deaths to be around 8 thousand or even lower. According to our modified mathematical modelling results, in order to change the course of the pandemic in Iran, effective individual and public precautions should definitely be taken urgently. The most effective individual precautions may be listed as paying maximal attention to hygiene, having a natural and healthy diet, increasing mobility and exercise and paying attention to social isolation.
\end{abstract}

Keywords: COVID-19, mathematical modelling, pandemic, precautions, public health 


\section{$\overline{\text { OZZ }}$}

SARS-CoV-2 veya COVID-19 olarak bilinen yeni koronavirüs, Çin'de Aralık 2019'daki ilk klinik vaka ile ortaya çıktı ve daha sonra çok hızlı bir şekilde küresel bir soruna dönüştü. İran, nüfusu 82531700 olan bir kalabalık Ortadoğu ülkesidir. 31.03.2020 tarihine kadar İran'daki vaka sayısı 44605'e ulaştı ve 2898 hasta hayatını kaybetti. Bu çalışmada, genel anlamda bulaşıcı hastalığa yakalanmış bireylerin P sayısının zamana göre değişim (yayılma) hızı; hastalığa yakalanmış olanların sayısı ile yakalanmamış olanların sayısının çarpımı ile orantılı olması bilgisinden yola çıkarak oluşturulan yeni bir modifiye özgün matematiksel modelleme üzerinden COVID-19 pandemisinin İran'daki gidişatının simüle edilmesi amaçlandı. Önlemler biraz artarsa, hastalığın ilerlemesi üzerine yansıması "üstsel" olacağı için, vaka sayısının 120 bine düşmesi ve ölümlerin 8 bin civarında olması bile mümkün görünmektedir. Modifiye matematiksel modelleme sonuçlarımıza göre, İran'daki pandeminin seyrini değiştirmek için etkili bir şekilde bireysel ve kamusal önlemler mutlaka acilen alınmalıdır. En etkili bireysel önlemler hijyene azami önem vermek, doğal ve sağlıklı beslenmek, hareketliliği ve egzersizi arttırmak ve sosyal izolasyona dikkat etmek olarak sıralanabilir.

Anahtar kelimeler: COVID-19, matematiksel modelleme, pandemi, önlemler, halk sağlığı

\section{INTRODUCTION}

The novel coronavirus which is known as SARS-CoV-2 or COVID-19 emerged in China with the first clinical case in December 2019, and afterwards, it has turned into a global problem very fast. COVID-19 starts with upper respiratory tract infection symptoms and may progress towards lower respiratory tract infections and respiratory distress. It may create a life-threatening situation as a result of viral pneumonia progressing with diffuse lung involvement. One of the countries in the world where it has progressed most rapidly is Iran [1-3]. In Iran, the first COVID-19 case was seen on 19.02.2020. Iran is a crowder Middle Eastern country with a population of 82531700 . Until 31.03 .2020 , the number of cases in Iran reached 44605, and 2898 patients lost their lives. COVID-19 infection, which is spread very fast, has reached pandemic conditions in Iran, as in the entire world [4]. The diagnosis of COVID-19 is made at molecular medicine laboratories with the method of reverse transcription-polymerase chain reaction. The fight against the pandemic has got easier with the help of RT-PCR analysis. However, in the diagnosis of the disease, while molecular analyses are important, clinical findings should definitely be considered. Additionally, classical viral infection findings may be seen with biochemical analyses, and radiological imaging may be useful in diagnosis [5]. Due to the rapid progression of the COVID-19 pandemic in Iran and the high numbers of infected and deceased cases, it is important to know about the progression of the disease in the near future. It is important to use scientific modelling to know about the number of cases in the near future and how much these potential numbers could be reduced with the universal precautions that could be taken. This study aimed to simulate the progression of the COVID-19 pandemic in
Iran with novel, modified mathematical modelling established based on the information that the timedependent change (spreading rate) in the number $P$ of the individuals who has caught a contagious disease is proportional to the multiplication of the numbers of those who have caught the disease and those who have not.

\section{METHOD}

It is known that the spreading rate of a contagious disease emerging in a region with a population $M$ is proportional to the multiplication of the numbers of those who have caught the disease and those who have not [6]. Where $\lambda$ is the proportional constant, this situation is expressed in the mathematical language with the following differential equation:

$$
\frac{d P}{d t}=\lambda P(M-P)
$$

Additionally, the model given by (1) in the literature was developed by Cakir and Savas in a way to simulate the COVID-19 pandemic trend in Turkey (7).

In this study, it was modified as "the spreading rate of the disease $\left(\frac{d P}{d t}\right)$ is directly proportional to the multiplication of the numbers of those who have caught the disease and those who have not and inversely proportional to the time variable" and analyzed specifically for the "COVID-19 pandemic in Iran". Accordingly, the mathematical model representing the progression of the disease in Iran was established in the form of: 


$$
\left\{\begin{array}{c}
\frac{d P}{d t}=\frac{63 r}{100 t^{0.37}} P(M-P) \\
P(0)=P_{0} \\
P\left(t_{1}\right)=P_{1}
\end{array}\right.
$$

The meanings assigned to the variables and parameters used in the model are shown below.

$t$ : time variable (in days),

$P(t)$ : number of patients at time $t$,

$\frac{d P}{d t}$ : derivative expressing the spreading rate of the disease,

$\lambda$ : a parameter containing all factors that affect the change in spreading based on time.

In addition to this, let us express the initial number of patients by $P(0)=P_{0}$ (at time $t=0$ ), the number of patients at a later time by $P\left(t_{1}\right)=P_{1}$ (at time $t=t_{1}$ ), and the highest possible number of patients as $M$.

In difference to the model (1) in the literature whose righthand side uses a proportionality constant $\lambda$, in our study, we used a function on the right-hand side explicitly including the variable $t$ as $\lambda(t)=\frac{63 r}{100 t^{0.37}}$. This choice of ours allowed us to establish a mathematical model that allows us to reach more realistic data in the form of a (2)-(4) initial value problem (IVP). Here, $r$ is a positive proportionality constant.

Now, let us solve the (2)-(4) initial value problem. For this, let us first take the differential equation (2) in type of separation of variables.

$$
\begin{gathered}
\frac{d P}{d t}=\frac{63 r}{100 t^{0.37}} P(M-P) \Rightarrow \frac{d P}{P(M-P)}=\frac{63 r}{100 t^{0.37}} d t \\
\Rightarrow \frac{P}{(M-P)}=c e^{M r t^{0.63}} \\
\Rightarrow P(t)=\frac{M c}{\left(e^{-M r t^{0.63}}+c\right)}
\end{gathered}
$$

Using the initial condition $P(0)=P_{0}$ in (5),

$$
P(0)=P_{0}=\frac{M c}{\left(e^{0}+c\right)} \Rightarrow c=\frac{P_{0}}{M-P_{0}} .
$$

Additionally, if the condition (4) is used to determine the parameter $r$ corresponding to the rate of spreading, it is seen that,

$$
\begin{aligned}
P\left(t_{1}\right) & =P_{1}=\frac{M c}{e^{-M r t_{1}^{0.63}}+c} \Rightarrow e^{-M r t_{1}^{0.63}}+c=\frac{M c}{P_{1}} \\
& \Rightarrow-M r=t_{1}^{-0.63} \ln \left(\frac{P_{0}\left(M-P_{1}\right)}{P_{1}\left(M-P_{0}\right)}\right) .
\end{aligned}
$$

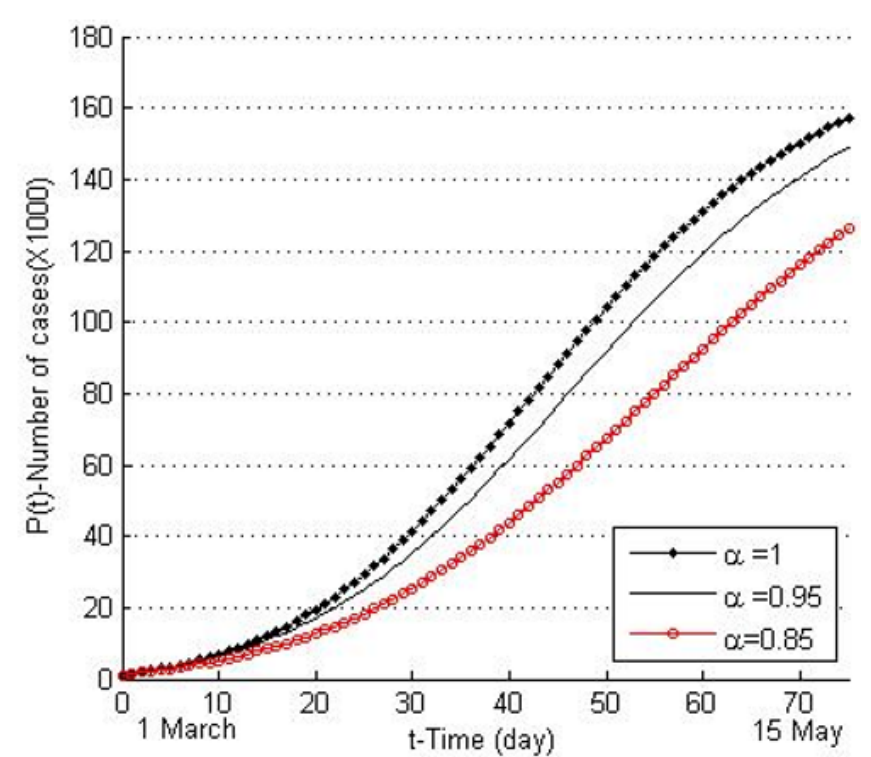

Figure 1. Changing in the number of cases between 1 March - 15 May 2020

Putting the expressions (6) and (7) in the formula (5), the solution of the (2)-(4) IVP is obtained as

$$
P(t)=\frac{M c}{\left(c+e^{-k t^{0.63}}\right)}
$$

Here, $k=\frac{1}{t_{1}^{0.63}} \ln \left(\frac{P_{1}\left(M-P_{0}\right)}{P_{0}\left(M-P_{1}\right)}\right)$, and it is a positive constant.

\section{RESULTS}

The behavior of the analytical function (8) we obtained as the theoretical solution of the (2)-(4) IVP represents the change in the number of patients in the period of 1 March 15 May. To analyze this change in more detail and more tangibly, the information that the actual number of patients on 1 March 2020 ( $t=0$-onset) was $P(0)=P_{0}=978$ individuals, and the actual number of patients on 31 March 2020 (taking $t_{1}=31$ ) was $P\left(t_{1}\right)=P(31)=P_{1}=44605$.

In the case that the potential number of patients that could catch the disease is $M=180000$, we may see the changing trend in the number of cases in a future 45-day period in Figure 1.

Based on the ratios of the cases and deaths reached by the day 31 March, the Corona-related death numbers expected for the one and a half months in the future are shown in

\section{Figure 2.}

In the case that current practices continue $(\alpha=1)$, it is expected for the number of cases to reach 160 thousand in mid-May, while the number of deaths is expected to exceed 10 thousand. 




Figure 2. Changing in the number of deaths between 1 March - 15 May 2020

If the precautions are increased a little bit, as its reflection on the progression of the disease would be "exponential", it seems possible for the number of cases to decrease down to around 120 thousand and for the deaths to be around 8 thousand or even lower. We are obtaining these inferences with the help of an a control parameter that expresses the exponential reflections of precautions which we added to the solution of the mathematical model we established.

In contrast, in the case of alleviating existing practices or the public not taking the situation seriously, it is clear that these numbers will go up even further.

\section{DISCUSSION}

According to our mathematical modelling results, if serious precautions are not taken, it is projected that approximately 120000 new cases will emerge in Iran, and the number of the deceased may exceed 10 thousand in the next 40 days. For this reason, with the help of taking public and individual precautions in Iran within a scientific framework and strict implementations of these, a significant reduction may be achieved. The amount of increase of the COVID-19 pandemic has an "exponential" change. This is why precautions to be taken will be very effective in reducing the spreading rate of the disease. According to the analysis results on our modified mathematical model that we are presenting in this study, even a small increase in the precautions will create a large difference in terms of patient numbers and the number of patients who will lose their lives. If serious rates of effective precautions are not taken, the course of the pandemic in Iran may display a very fast change in the negative direction. For these reasons, every individual or social precaution to be taken in Iran will be very significant in terms of controlling the COVID-19 pandemic and overcoming it with fewer losses. Our previous mathematical modelling results reflecting the situation in Turkey showed numerical differences, while they had similarities to Iran in terms of behaviors towards precautions. As in Turkey, with a small amount of effective precautions, it will be possible to highly reduce the number of cases in Iran. Our research results numerically demonstrate this situation (7).

\section{CONCLUSION}

According to our modified mathematical modelling results, in order to change the course of the pandemic in Iran, effective individual and public precautions should definitely be taken urgently. The most effective individual precautions may be listed as paying maximal attention to hygiene, having a natural and healthy diet, increasing mobility and exercise and paying attention to social isolation. Being confined at home for social isolation may lead to a more sedentary life and an unhealthy diet. This situation weakens the immune system. We should be mobile within the home and regularly do simple exercises. Additionally, efforts should be spent to eat healthy. This way, the spreading rate of the disease will decrease, and as the immune system is strengthened, the mortality rate of patients diagnosed with COVID-19 will decrease. It should be noted that smoking is a fact that increases the risk factor related with COVID-19. Vitamin and antioxidant supplements are thought to be beneficial in prophylaxis and treatment. Additionally, in the public sense, it is necessary to make official regulations towards social isolation, diagnose suspicious cases by applying molecular tests fast, isolate patients and protect especially the elderly more.

\section{DECLARATION OF CONFLICT OF INTEREST}

The authors received no financial support for the research and/or authorship of this article. There is no conflict of interest.

\section{REFERENCES}

1. Soldati G, Smargiassi A, Inchingolo R, Buonsenso D, Perrone T, Briganti DF, et al. Proposal for international standardization of the use of lung ultrasound for COVID19 patients; a simple, quantitative, reproducible method. J Ultrasound Med 2020. (doi: 10.1002/jum.15285).

2. Hu TY, Frieman $M$, Wolfram J. Insights from nanomedicine into chloroquine efficacy against COVID19. Nat Nanotechnol 2020. (doi: 10.1038/s41565-0200674-9. 
3. Mousavi SH, Shah J, Giang HTN, Al-Ahdal TMA, Zahid SU, Temory $F$, et al. The first COVID-19 case in Afghanistan acquired from Iran. Lancet Infect Dis 2020. (doi: 10.1016/S1473-3099(20)30231-0).

4. Coronavirus Infection Map. Available at: https://www. worldometers.info/coronavirus/country/iran/ (Accessed April 1, 2020).

5. Lippi G, Plebani M. The critical role of laboratory medicine during coronavirus disease 2019 (COVID-19) and other viral outbreaks. Clin Chem Lab Med 2020. (doi: 10.1515/cclm-2020-0240).
6. Edwards $\mathrm{CH}$, Penney DE. Differential Equations and Boundary Value Problems: Computing and Modeling. 5th ed. Pearson Prentice Hall. USA. 2008.

7. Cakir Z, Savas HB. A Mathematical Modelling Approach in the Spread of the Novel 2019 Coronavirus SARS-CoV-2 (COVID-19) Pandemic. Electron J Gen Med. 2020; 17(4): em205. (doi: 10.29333/ejgm/7861). 